\title{
The Role of PrajasthapanaYoga and Phalaghrita Uttarbasti in Management of Infertility W.S.R. Cervical Factor
}

\author{
Research Article
}

\author{
Jasmina Acharya ${ }^{1^{*}}$, Mistry $\mathrm{IU}^{2}$ \\ 1. Reader, J.S. Ayurved Mahavidyalaya, Nadiad, Gujarat \\ 2. Ex.HOD \& Prof, IPGT \& RA, Jamnagar, Gujarat
}

\begin{abstract}
Vandhyatva (infertility) has been a long standing problem since ancient times.Many herbal and herbomineral formulations are mentioned as treatment of infertility in the ancient texts,but they are not categorized according to the responsible factor of infertility.It is need of the hour to evaluate the efficacy of formulations with respect to various factors. With the above aim a clinical study was conducted to evaluate the efficacy of Prajasthapana Yoga and PhalaghritaUttarbasti on cervical factor i.e scanty cervical mucus.For clinical trial total 7 patients were selected for this study.4 tab.(2 gm)of Prajasthapana Yogawas given orally thrice a day for 2 month and intracervical Uttarbasti of Phalaghrita $(3 \mathrm{ml})$ was administered in every sitting for 6 days after end day of menses subsequently for two cycles.Sims Huhner and Moghissi cervical mucus Test and post coital testwere selected for the diagnosis and for evaluation of efficacy of therapy on cervical factor.Statistically highly significant result were found on quantity and viscosity $(\mathrm{p}<0.001)$ and significant result were found inferning,cellularityand spinnbarkeit $(\mathrm{p}<0.05)$. Hence, in nutshell it was concluded that Prajasthapna Yoga and PhalaghritaUttarbasti showed good results in all the properties of cervical mucus.
\end{abstract}

Keywords: Vandhyatva, Uttarbasti, Phalaghrita,PrajasthapanaYoga, Cervical factor, Infertility.

\section{Introduction}

In the present scenario of the rapid advancement in technology,infertility is still aproblem that has continued since ages. Many factors are responsible for female infertility, which is Tubal factor $-40 \%$, ovarian factor- $05 \%$,cervical factor $-20 \%$ and uterine factor-10\%J.M Sims (1868) first identified cervical factor in infertility(1). The cervical mucus acts as filter allowing only single functioning to penetrate cervical mucus. When this is hostile and unfavorable it reduces the quality or quantity of sperm,affect sperm viability and ultimately leads to infertility.AcharyaSushruta has described the essential factors for conception i.eRitu(season or ovulatory period),Kshetra (field i.ereproductive organs) and $A m b u$ (water i.enutritive material\&hormones) which are responsible to maintain the pregnancy and defect in either of these factors may result in to infertility(2).

Less quantity and poor quality of cervical mucus may be due to inadequate estrogen level or less utilization of estrogen through receptor is the main factor of infertility caused by cervical factor.Proper secretion of cervical mucus is a resultand of balanced Tridosha(three humors of body) Prasada Rasa dhatu

*Corresponding Author:

Jasmina Acharya

Reader,

J.S. Ayurved Mahavidyalaya,

Nadiad, Gujarat

Email Id: jdachrya1@gmail.com (essence plasma or nutrients),Raktadhatu (blood), Mamsadhatu (muscles,tissues)and Sthanika Agni(local metabolism at cellular level) according to Ayuveda,Functions of cervical mucus can belinked with the Kledana Karma(moisturizing action)of Kapha.Vata vitiated due to RukshaGuna (dry Property) and TikshnaGuna (penetrating or pungent property)is mainly responsible for reduction in cervical mucus.Treatment of Vandhyatva (infertility) is broadly classified into two groups i.eTaila(oil) treated conditions or Ghritatreatedconditions. The choice of Taila (oil) or Ghrita depends on the accompanying Doshas withVata.If Vata is associated with Kapha,Taila has to be preferred,while in case of Pitta association, Ghrita has to be preferred (3).considering this concept Phalaghritaand Prajasthapana Yoga were selected for the present trialAs per classics the drugs mentioned in Prajasthapana Yoga have Prajasthapna effect. All herbs are Rasayana and Balya.Thereby the formulation of Prajasthapana Yoga found very effective in Vandhyatva.Uttarbasti is one type of Basti which is best for the disease of female. It tones up reproductive organs and improves the quality of Ambui.e cervical mucus . Thus by applying proper drug through Uttarbasti, disorders of female reproductive tract can be cured. Hence, this study was planned to evaluate the efficacy of PhalaghritaUttarbasti and Prajasthapana Yoga on cervical factor responsible for infertility.

\section{Materials and Methods Selection of Patients}

Patients $(\mathrm{n}=7)$ suffering from infertilitydue to cervical factor were registered from O.P.D of Prasuti- 
Streeroga (Gyneac),Department IPGT\& RA, Jamnagar, irrespective of cast, religion etc. Informed written consent was taken all the patients.The study was approved by the Institutional ethics Committee.

\section{Criteria for Diagnosis}

Based onMoghissi mucus scale (Cervical mucus test)\& Post Coital Test (PCT): for diagnosis of Cervical Factor(5).

\section{Criteria for selection of Patients}

Primary and Secondary both types of infertile patients have been selected form study. Patients having poor cervical mucus, (functional abnormality of $\mathrm{Cx}$ mucus) and abnormal PCT were selected for present study.

\section{Exclusion criteria}

The patients who had the problems such as anovulatory,structural abnormalities of cervix and blockage of both tubes were excluded.

\section{INVESTIGATIONS:}

Endometrial Biopsy \& Hysterosalpingography, investigations were carried out to rule out ovarian and tubal factor of infertility. Routine hematological and urine investigations were carried out to rule out underlying other pathologies.

\section{CRITERIA FOR ASSESSMENT:}

The criteria for assessment of treatment are based on Sims Huhner andMoghissi's score for cervical mucus and Post coital test.

The cervical mucus score is as follows:

\section{Amount}

$$
\begin{aligned}
& <0.1 \mathrm{ml}=0 \\
& =0.1 \mathrm{ml}=1 \\
& =0.2 \mathrm{ml}=2 \\
& >0.3 \mathrm{ml}=3
\end{aligned}
$$

\section{Viscosity}

Thick, highly viscous $=0$

Intermediate type $=1$

Mildly viscous $=2$

Thin $=3$

\section{Ferning}

No crystallization $=0$

Atypical fern formation $=1$

Primary / Secondary $=2$

Spinnbarkeit

$$
\text { Tertiary }=3
$$

$$
\begin{aligned}
& <1 \mathrm{~cm} .=0 \\
& 1 \text { to } 4 \mathrm{~cm} .=1 \\
& 5 \text { to } 8 \mathrm{~cm} .=2 \\
& >9 \mathrm{~cm} .=3
\end{aligned}
$$

\section{Cellularity}

$>11$ cells $/$ hpf. $=0$

6 to 10 cells $/ \mathrm{hpf} .=1$

1 to 5 cells $/$ hpf. $=2$

0 cells $/ \mathrm{hpf} .=3$

\section{Density of sperm}

Dead / No sperm /hpf. $=0$
2 to 5 sperm $/$ hpf. $=1$

5 to10 sperm $/$ hpf. $=2$

$>10$ to 15 sperm $/$ hpf. $=3$

\begin{tabular}{|c|c|}
\hline Cured & $\begin{array}{lll}100 \% \text { result } & \text {,increase } & \text { in } \\
\text { cervical mucus } & \text { score }>10 & \& \\
\text { conception } & & \\
\end{array}$ \\
\hline Markedly Improved & $\begin{array}{l}75 \% \text { result, increase } \\
\text { cervical mucus score }>10 .\end{array}$ \\
\hline Moderately Improved & $\begin{array}{l}50 \% \text { result, increase in } \\
\text { cervical mucus score }<5\end{array}$ \\
\hline Improved & $\begin{array}{l}25 \% \text { result, increase in } \\
\text { cervical mucus score }>5 \text {. }\end{array}$ \\
\hline Unchanged & $\begin{array}{l}0 \% \text { result, No change in the } \\
\text { cervicalmucus } \\
\text { aftertreatment. }\end{array}$ \\
\hline
\end{tabular}

Motility of sperm

Immotile $=0$

Insitu motile $=1$

Sluggishly $=2$

Rapid $=3$

Criteria for assessment of overall effect of therapy Table No.1 Showing the total effect of therapy on the basis of percentage relief

\section{TREATMENT PROTOCOL}

Selection of Drugs:

Phalaghrita and Prajasthapana Yogahave been selected for drug trial.Phalaghrita (4) was preparedin Department of Rasa Shastra and BhaishajyaKalpana, I.P.G.T. \& R.A., Jamnagar. Prajasthapana Yoga (Anubhuta) was prepared in the pharmacy of Gujarat Ayurved University, Jamnagar.

Table No.2 Showing the ingredients of Prajasthapana Yoga

\begin{tabular}{|l|l|l|}
\hline Sr. No. & Ingredients & Part \\
\hline 1 & Shatavari & 1 \\
\hline 2. & Atibala & 1 \\
\hline 3. & Amalaki & 1 \\
\hline 4. & Nagakesara & 1 \\
\hline 5. & Vatankura & 2 \\
\hline 6. & $\begin{array}{l}\text { Durvasvarasa } \\
\text { (Bhavnadravya) }\end{array}$ & Q.S. \\
\hline
\end{tabular}

\section{DRUGS \& POSOLOGY}

After proper diagnosis, all patients were given Prajasthapana Yoga in below mentioned posology followed by Uttarbasti of $3 \mathrm{ml}$ Phalaghritafor 6 days after completion of menses in a month.

- Dose:4 tab (2gm) thrice a day orally

- Anupana: warm milk

- Duration of Treatment: 2 months FOLLOW -UP STUDY:

2 month follow -up for pregnancy or any late complications carried out after the completion of treatment.Any new complaint appeared during follow up period related to study was also noted. 


\section{Observations}

Total 7 patients were registered.06 patients had completed full course and remaining 01 patient left the course incomplete.Maximum number of patients i.e. $28.57 \%$ were registered of the age between 21-23 yrs.,27-29 yrs, and 30-32 yrs each age group. The distribution of the patients according the duration of their chief complaint shows that a majority of patient i.e. $42.86 \%$ had the complaint since $1-3$ years, $28.57 \%$ of patients had the complaint since 4-6 years and 28.57 $\%$ patients had the complaint since $7-9$ years.

Distribution of patients according to their associated complaint show that maximum number of patients i.e $57.14 \%$ had no complaint $28.57 \%$ of patients had painful menstruation while $14.29 \%$ of patients had scanty menstruation.

All the patients had regular menstrual cycle. Nearly $71.43 \%$ patients had moderate quantity of menses..All the patients showed absence of white discharge and cervical erosion.The $71.53 \%$ of patients were Pitta-Kapha Prakriti. 85.71\% of patients had katu Rasa dominancy in their diet.

\section{Results}

Statistical test

Based on observations, the data obtained were statistically analyzed in terms of mean,standard deviation, standard error and unpaired ' $t$ ' test was considered at the level of $\mathrm{p}<0.001$ as highly significant, $\mathrm{p}<0.05$ or $\mathrm{p}<0.01$ as significant and $\mathrm{p}>0.05$ as insignificant to assess the result.

\section{Effect on cervical mucus:}

The effect of therapy on cervical mucus was found in all the patients. Analysis of the data related to improvement in highly significant $(\mathrm{P}<0.001)$ relief in amount (66.67\%)of mucous, viscosity(77.78\%) ofmucous.Statically significant result $(\mathrm{P}<0.05)$ was obtained on ferning,(40\%)Spinnbarkeit $(41.18 \%)$, Cellularity $(28.57 \%)$ i.e. shown in Table-3.

Table no -3 Effect of Phalaghrita cervical Uttarbasti and Prajasthapana Yoga on cervical mucous

\begin{tabular}{|c|c|c|c|c|c|c|c|}
\hline $\begin{array}{c}\text { Cervical } \\
\text { properties }\end{array}$ & \multicolumn{2}{|c|}{ Mean score } & Relief\% & S.D & S.E & t & P \\
\cline { 2 - 3 } & B.T & A.T & & & & & \\
\hline Amount & 0.83 & 2.50 & 66.67 & 0.52 & 0.21 & 7.91 & $<0.001$ \\
\hline Viscosity & 0.67 & 3.00 & 77.78 & 0.82 & 0.33 & 7.00 & $<0.001$ \\
\hline Ferning & 1.50 & 2.50 & 40 & 0.63 & 0.26 & 3.87 & $<0.05$ \\
\hline Spinbarkeit & 1.67 & 2.83 & 41.18 & 0.75 & 0.31 & 3.80 & $<0.05$ \\
\hline Cellularity & 1.67 & 2.33 & 28.57 & 0.52 & 0.52 & 3.16 & $<0.05$ \\
\hline
\end{tabular}

The data pertaining to the effect on PCT revealed statistically insignificant result $(\mathrm{P}>0.1)$ on density of sperm $(70 \%)$.On motility of sperm $(100 \%)$,statistically insignificant result $((\mathrm{P}<0.1)$ was observed due to small size of data.i.e. shown in Table-4.

Table no - 4 Effect of Phalaghrita cervical Uttarbasti and Prajasthapana Yoga on Sperm Density and Motility

\begin{tabular}{|c|c|c|c|c|c|c|c|}
\hline $\begin{array}{c}\text { Factor of } \\
\text { cervical } \\
\text { mucus }\end{array}$ & $\mathbf{2}$ & Mean score & Relief (\%) & S.D. & S.E. & t & 'P' \\
\cline { 2 - 6 } & $\mathbf{A . T}$ & & & & & \\
\hline $\begin{array}{c}\text { Density of } \\
\text { sperm }\end{array}$ & 0.50 & 1.67 & 70 & 0.98 & 0.40 & 0.40 & $>0.1$ \\
\hline $\begin{array}{c}\text { Motility } \\
\text { of sperm }\end{array}$ & 00 & 1.00 & 100 & 1.10 & 0.45 & 2.24 & $<0.1$ \\
\hline
\end{tabular}

$33.33 \%$ of patients conceived (cured), $50 \%$ of patients were markedly improved, $16.67 \%$ of patients were moderately improved. None of the patients remained unchanged out of the 6 patients i.e. shown in Table- 4 .

Table No - 5 Total effect of therapy

\begin{tabular}{|l|l|l|}
\hline Effect of therapy & No. of patients & Percentage \\
\hline Completely cured & 2 & 33.33 \\
\hline Markedly improved & 3 & 50 \\
\hline Moderately improved & 1 & 16.67 \\
\hline Improved & 0 & 00 \\
\hline Unchanged & 0 & 00 \\
\hline
\end{tabular}




\section{Discussion}

Prajasthapana yoga

Prajasthapana Yoga contains mainly

Madhura,Tikta and Kashaya Rasa, Laghu, Ruksha Guna,both Madhura Vipaka and also Shita Virya. It also has Dipana, Anulomana, Shothahara, Rasayana, Garbhasthapana properties. It alsohas anti-bacterial, anti-fungal, antioxidant, anti-inflammatory, antiabortifacient and immunomodulatory. (6),(7),(8)

\section{Phalaghrita}

As already described that Ghrita has Tridoshaghna karma due to its properties(9) and milk is also Vata Pitta shamaka, Jivaniya and Rasayana. So,Phalaghrita has the properties of ghrita, milk and other ingredients it contains.Phalaghrita contains mainly Tikta, Madhura and Katu Rasa.Laghu, SnigdhaGuna, both Katu and MadhuraVipaka and also Ushnaa and Sheeta Virya. It also has Dipana, Pachana, Anulomana, Shothahara, Krimighna and Prajasthapanaproperties. As describe previously, about the action of uttarbasti phalaghrita uttarbasti nourishes and regenerates the epithelial cells.

\section{Action of drug on cervical factor:}

Action of Prajasthapana yoga and Phalaghritaon each characteristic of cervical mucus are as follows:

\section{Amount}

Anabolic action of drug increases more secretary units and proper estrogenic effect on cervical epithelium,due to proper function of receptor mechanism thus the cervical mucus increases in amount.

\section{Viscosity and Spinnbarkeit}

It decreases picchilata of kapha and increases thinness (fluidity) of mucus due to laghuguna,the viscosity decrease and hence spinnbarkeit increases.

\section{Cellularity}

It decreases the debris by anabolic properties, thus the mucus becomes clear.

\section{Fern}

Dipana,Anulomana and Pachanakarma does the proper Oestrogenic effect on cervical mucus and results in proper ferning.

pH

Shita and snighagunas inhibit the Ushna andTikshnagunas of Pitta and decrease acidic mucus.

As per the result, it can be said that increase in amount of cervical mucus and viscosity, ferning, spinbarkeit, Decrease in cellularity was observed due to anabolic effect of Shatavari. Increased amount of cervical mucus was observed due to its local regenerative effect on secretory unit of the cervix. The anabolic effect of Phalaghrita and Prajasthapana Yoga was observed on patients of infertility, which was reported with increment of cervical mucus along with enhanced Agni.

It was also observed that the patients suffering from scanty menses before the treatment, they got a normal period. It may be due to Vatapitta Shamaka property of drugs and phytoestrogenic or estrogen properties of Prajasthapana Yoga (Shatavari). This drug after metabolism enters in to blood, in hypothalamus estradiol is converted in to catacholestrogen 2hydroxylase enzymes. Catechlestrogen may influence GnRH release regulate hypothalamus pituitary ovarian axis and regulate Reproductive function.(9).

\section{Image no. 1 Shown the Diagram of drug action}

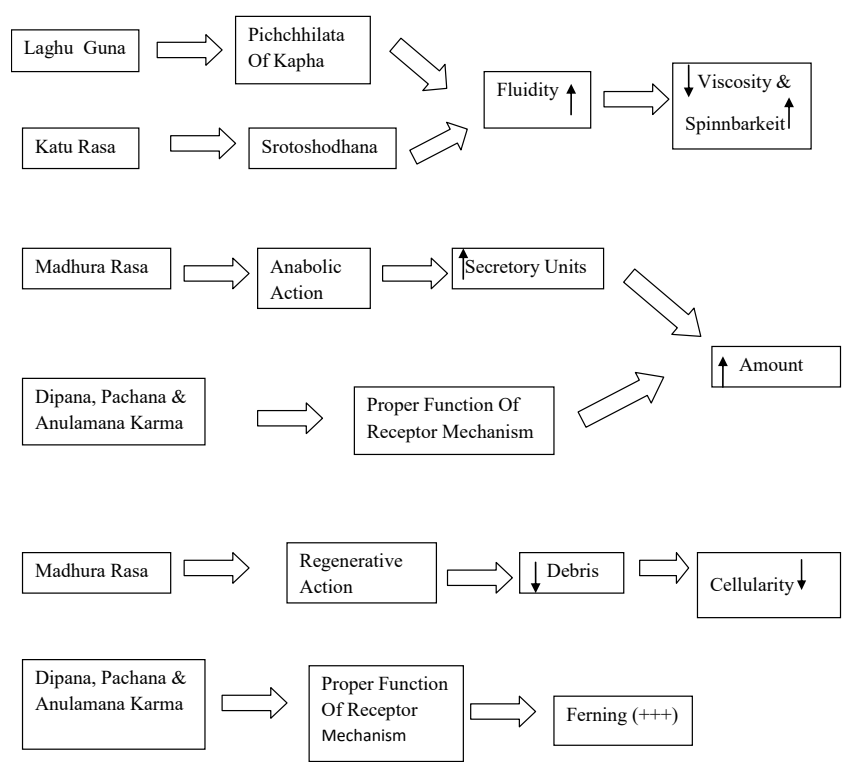

\section{Conclusion}

From the above discussion, it can be concluded that though the percentage of cervical factor( $20 \%)$ in Vandhyatva(Infertility) is less than other factors, but it is as important causative factor due to its adverse effect on sperm penetration.So, for healthy mucus patient should be taken Balya, Brumhana and Madhuraahara and avoid Ushna, Tikshnaahara. They should be remained free from Krodha, Chinta, Shokaetc. which have great role to create, abnormalities in almost all causative factors of Vandhyatva. Lastly The results of study reveal that the Prajasthapana Yoga with PhalaghritaUttarbasti was very effective therapy on the cervical factor.Also it can conclude that combine therapy had good anabolic effect on the whole body as well as uterus, the effect of Prajasthapana Yoga and Phalaghrita both drugs have good effect to increase the status of cervical mucus . Hence,Prajasthapana Yoga with PhalaghritaUttarbasti is recommended for the patient of infertility due to cervical factors.

\section{References}

1. Dawn CS-Textbook of Gynaecology and contraception-12 th, Calcutta-Dawn books . 1996, $215 \mathrm{p}$

2. Ambikadatta Shastry,SusrutaSamhita-part 1 sharirasthana, AyurvedatatvaSandipikaVaranasi,ChaukhambhaSankritaSansthana- 2011, 19 $\mathrm{p}$

3. YadavajiTrikamjiAcharya, CharakaSamhita with AyurvedaDipika commentary by Chakrapani, Part -1 (nidanasthana), (Sutrasthapana), 5 th, Varanasi 
Chaukhambha Sanskrit Santhana,483,182 p.

4. Sharagadhara, ShargadharaSamhita, $3^{\text {rd }}$, with the commentary ofRajvaidyashriRasiklalJehalal Parikh,Ahmedabad, SastusahityaVardhaka Karyalaya1971 339-340 p.

5. Mary G.Hammond \& Lather M. Talbert- A Practical Guide For The Physician ,3rd,Boston Blackwell scientific publication ,1992, $70 \mathrm{p}$

6. Sharma PC,M.B.Yelne,T.J.Dennis,Data base of Medicinal Plants used in a Ayurveda Vol-1 New Delhi, CCRAS 2002, .50, 418,280p

7. Sharma PC,M.B.Yelne, T.J.DennisData base of
Medicinal Plants used in a Ayurveda, Vol-3,New Delhi CCRAS 2005, 11, 548p

8. Billore KV, M.B.Yelne, T.J.Dennis, B.G.Chaudhari Data base of Medicinal Plants used in a Ayurveda, Vol-6,New Delhi CCRAS 2005, 38p

9. Jeffcoate N.-.Jeffcoate's Principles of Gynecology$7^{\text {th }}$,New Delhi,Jaypee brothers Medical Publishers (P) Ltd.2008,73p

10.Dutta DC,- D.C.Dutta's Text book of Gynecology, 7 th,New Delhi, JAYPEE Brothers Medical Publishers (P) Ltd,2016,188p 